\title{
PATIENTS’ SATISFICATION AS THE QUALITY INDICATOR OF NURSING
}

\author{
Gunta Beta \\ Rīga Stradiņš University, Latvia \\ Dita Role \\ Rīga Stradiņš University, Latvia \\ Dina Berloviene \\ Rīga Stradiņš University, Latvia \\ Zane Balkena \\ Rīga Stradiņš University, Latvia
}

\begin{abstract}
Patients, during their stay at hospital, have the right to receive qualitative care and patients' wellbeing depends on it. Patients' wellbeing is based on satisfaction with care, which is influenced by, made by several conditions: communication of nurses, professionalism, education and timely provision thereof. Research aim: analyse the satisfaction of patients with the care provided by nurses. Research methods: Quantitative research method - original questionnaire "Newcastle Satisfaction with Nursing Scale" (NSNS).The results of the research: Patient who gives the assessment on nursing quality, with his sense of health condition of the specific period, general and individual requirements, personalized wishes and expectations can influence the satisfaction assessment, because he always is the source subjective variations. Even though the level of patients' satisfaction is important and considerable indicator for nursing quality, by means of which it is possible to determine the efficiency of the provided care. This is a real means to identify the implemented fields of nursing aims, and improve the process if required, to ensure the quality. Nursing quality is based on patient-centred approach to achieve the common preferable health-care results.
\end{abstract}

Keywords: nursing, nursing quality, patient's satisfaction.

\section{Introduction}

Assessment of nursing quality and provision thereof became the health-care concern already in 1970s and 1980s (Ozga, Gutysz-Wojnicka, Wojtaszek, \& Lewandowski, 2014). "Nursing" is a very important aspect on which patients' satisfaction depends, because nurses are involved in almost all aspects of care in a hospital (Ahmed, Assefa, Demisie, \& Kenay, 2014).

According to the health-care data from the Centre for Disease Prevention and Control, the number of hospitalized patients increases over the last years, but the 
number of practising nurses shrinks, that's why it is important that the health-care quality wouldn't deteriorate (SPKC, 2017).

Patients' satisfaction is used more and more in many hospitals as the quality indicator, because patients who are satisfied with the care are of importance for the hospital - they observe more the instructions and suggestions of health-care experts and most likely they will continue using the health-care services and will suggest the hospital to others (Piredda et al., 2015). Whereas, an unsatisfied patient prematurely interrupts the treatment, doesn't cooperate in the care and treatment process, and look for the help elsewhere (Gutysz - Wojnicka, Dyk, Cudak, \& Ozga, 2013). Assessment of patient care is a real means to provide the care improvement possibilities.

The factors determining the patients' satisfaction in nursing can be related with assessment of diverse competences or entrustable professional skills (Ten Cate et al., 2015) or practicing nurses in clinical environment the preference whereof must be assessed in three fields: amount of nurse's communication with the patient, education of patients and professional action in the context of situation. The definition of the entrustable professional skills is not yet acquired in the health-care education in Latvia and in the professional practice, but it includes activities recognizable in the standard of nurse profession and in the patient-care (interpersonal contact and communication, education of patients) which form the patients' satisfaction. Integration thereof causes trust to nursing and these are important elements of safe patient-care.

\section{Characterization of patients' satisfaction}

Patients expect individualized, professional nursing and non-missing wish to help that can explain the differences in patients' satisfaction if the provided nursing can differ from the expectation of patients.

And most of the patients want to receive information about their health condition, participate actively in its planning, managing and decision-making in relation with the treatment options and care (Milutinovic, Simin, Brkić, \& Brkić, 2012).

One of the most common problems for doctors and nurses is that the action is disease-centred, the work is mainly oriented to hospital or task not to the person (Gustafson, 2015; Oflaz \& Vural, 2010). In this case the patient can feel impersonal which in turns can influence his/her perception of nursing principles.

Nurses interact with patients more frequently than any other health-care staff in a hospital. A nurse is mainly the one who explains the information provided by doctors to patients in a more comprehensible form (Ahmed et al., 2014; Negarandeh, Abbas, \& Mamaghani, 2014). 
There is no agreed definition on what patients' satisfaction is. Definitions from different authors can be found (Gutysz - Wojnicka et al., 2013; Findik, Unsar, \& Sut, 2010; Ahemd et al., 2014). The most accurately it is defined by Eriksen: 'Patients' satisfaction is the assessment of patients' subjective, cognitive and emotional response that results from interaction between expectations about nursing and actual attitude of nurses.” (Maqsood, Oweis, \& Hasna, 2012). Considering the different definitions of patients' satisfaction assessment of patients' satisfaction is a complicated task, it is multidimensional and subjective.

A group of authors Kvist et al. (Kvist, Voutilainen, Mäntynen, \& Vehviläinen-Julkunen, 2014) carried out a research the aim whereof was to analyse how the satisfaction of nurses with their work and organizational characteristics (of hospital and unit) influence the perception of patients about the quality of care. It was concluded that patients' perception of overall quality of care is positively related with overall satisfaction of nurses with their work.

A similar study was carried out by a group of researchers Papastavrou et al. (Papastavrou, Andreou, Tsangari, \& Merkouris, 2014). Also, in this research it was discovered that patients' satisfaction is influenced by how nurses perceive their work, working environment and organizational issues. It points to the fact that the quality of care can be improved adapting the factors that influence the satisfaction with work (Kvist et al., 2014).

\section{Methodology}

Aim of the research: analyse the satisfaction of patients with the care provided by nurses.

Research participants: 100 patients from internal medicine units in equal proportions which are selected by means of non-probability sample. The inclusion criteria for respondents: older than 18 years, they are in the units for 48 hours or more and they agree to participate in the research.

Tools: Quantitative research method - questionnaire was used to carry out the research applying the original questionnaire "Newcastle Satisfaction with Nursing Scale" (NSNS). The levels of satisfaction create continuity and they can be assessed "from - to" (complete lack of satisfaction - completely satisfied, by means of Likert scale).

\section{Research results}

50 patients were questioned in each of the internal diseased units, in total they were 100 respondents at the age from 18- 87 years. The average age of respondents 55.8 years, from which 39 were male, but 61 - female patients. The average stay in the hospital 5.21 days (Min 2, Max 24). 
The total patients' satisfaction result in unit $\mathrm{A}$ is $73.0 \%$, but in unit $\mathrm{B}$ $75.1 \%$, which gives the total satisfaction results $-74.1 \%$. In patients' satisfaction with the nursing care the highest evaluation was given in the questions: "How quickly nurses came when you called for them", "How capable nurses were at their job" and "Availability of nurses in cases of need", but the lowest evaluation was given in the questions: "How much information nurses gave to you about your conditions and treatment" and "The type of information nurses gave to you about your condition and treatment” (see Table 1).

Table 1 Satisfaction with nursing care

\begin{tabular}{|l|c|c|c|}
\hline & Mean & SD & $\%$ \\
\hline 1. How much time nurses devoted to you & 3,05 & 0,821 & 76,3 \\
\hline 2. How capable nurses were at their job & $\mathbf{3 , 3 6}$ & $\mathbf{0 , 7 1 8}$ & $\mathbf{8 4 , 0}$ \\
\hline 3. Availability of nurses in cases of need & $\mathbf{3 , 3 0}$ & $\mathbf{0 , 8 7 0}$ & $\mathbf{8 2 , 5}$ \\
\hline 4. The amount nurses knew about your care & 2,85 & 0,968 & 71,3 \\
\hline 5. How quickly nurses came when you called for them & 3,39 & 0,909 & 84,8 \\
\hline 6. The way the nurses made you feel at home & 2,55 & 1,132 & 63,8 \\
\hline $\begin{array}{l}\text { 7. How much information nurses gave to you about your } \\
\text { conditions and treatment }\end{array}$ & $\mathbf{2 , 1 2}$ & $\mathbf{1 , 1 1 3}$ & $\mathbf{5 3 , 0}$ \\
\hline 8. How often nurses checked to see if you are okey & 2,79 & 1,104 & 69,8 \\
\hline 9. Nurses' helpfulness & 3,23 & 0,874 & 80,8 \\
\hline 10. The way nurses explained things to you & 2,99 & 0,969 & 74,8 \\
\hline 11. How nurses helped put your relative's or fiends' minds at rest & 2,73 & 1,043 & 68,3 \\
\hline 12. Nurses' manned when performing their duties & 3,28 & 0,766 & 82,0 \\
\hline $\begin{array}{l}\text { 13. The type of information nurses gave to you about your } \\
\text { condition and treatment }\end{array}$ & $\mathbf{2 , 4 6}$ & $\mathbf{1 , 0 7 7}$ & $\mathbf{6 1 , 5}$ \\
\hline 14. Nurses' treatment of you as an individual & 2,79 & 1,028 & 69,8 \\
\hline 15. How nurses listened to your worries and concerns & 2,88 & 0,977 & 72,0 \\
\hline 16. The amount of freedom you were given on the ward & 3,30 & 0,870 & 82,5 \\
\hline 17. How willing nurses were to respond to your requests & 3,29 & 0,832 & 82,3 \\
\hline 18. The amount of privacy nurses gave you & 2,90 & 0,980 & 72,5 \\
\hline 19. Nurses' awareness of your needs & 3,02 & 0,899 & 75,5 \\
\hline
\end{tabular}

The total statistical assessment of patients' impressions in unit $\mathrm{A}$ is 67\%, but in unit $\mathrm{B}-67.7 \%$, which gives the total result $-67.4 \%$. In patients' impressions about the provided nursing care, the highest assessment was given to the statement "Nurses were too easy going and laid back", meaning that $80 \%$ of respondents answered that they don't agree to this. Also, the questions "Nurses used to go away and forget what patients had asked for", "Doctors and nurses worked well 
together as a team" and "Nurses made me do things before I was ready" got high results meaning that $73.9 \%$ of the questioned patients recognized that they don't agree to it. The question "Nurses explained me my health condition" got the lowest evaluation where only a bit less than half of respondents (47.55) answered that they don't agree to is (see Table 2). The questions "Nurses had time to sit and talk to me", "Nurses knew what to do not relying on the doctors" and "Nurses did not tell me enough about my treatment" also got low evaluation.

\section{Table 2 Impressions about nursing care}

\begin{tabular}{|l|c|c|c|}
\hline & Mean & SD & $\%$ \\
\hline 1. It was easy to have a laugh with the nurses & 4,48 & 1,193 & 74,8 \\
\hline *2. Nurses favoured some patients over others & 4,19 & 1,587 & 69,8 \\
\hline *3. Nurses did not tell me enough about my treatment & 2,98 & 1,723 & 49,8 \\
\hline *4. Nurses were too easy going and laid back & 4,80 & 1,255 & 80,0 \\
\hline 5. Nurses took a long time to come when they were called & 4,46 & 1,642 & 74,3 \\
\hline 6. Nurses gave me information just when I needed it & 4,29 & 1,452 & 71,5 \\
\hline *7. Nurses did not seem to know what I was going through & 3,99 & 1,345 & 66,5 \\
\hline *8. Nurses turned the light off too late at night & 4,67 & 1,198 & 77,8 \\
\hline 9. Nurses made me do things before I was ready & 4,76 & 1,156 & 79,3 \\
\hline 10. No matter how busy nurses were, they made time for me & 4,61 & 1,118 & 76,8 \\
\hline 11. I saw nurses as friends & 3,23 & 1,588 & 53,8 \\
\hline 12. Nurses spent time comforting patients who were upset & 3,60 & 1,356 & 60,0 \\
\hline *13. Nurses checked regularly to make sure I was okey & 4,12 & 1,486 & 68,7 \\
\hline *14. Nurses let things get on top of them & 4,28 & 1,248 & 71,3 \\
\hline *15. Nurses took no interest in me as a person & 3,42 & 1,615 & 57,0 \\
\hline 16. Nurses explained me my health condition & 2,85 & 1,872 & 47,5 \\
\hline 17. Nurses explained what they were going to do to me before they & 4,34 & 1,616 & 72,3 \\
\hline did it & & & \\
\hline 18. Nurses told the next shift what was happening with my care & 4,15 & 1,250 & 69,2 \\
\hline *19. Nurses knew what to do without relying on doctors & 2,99 & 1,573 & 49,8 \\
\hline *20. Nurses used to go away and forget what patients had asked for & 4,77 & 1,136 & 79,5 \\
\hline 21. Nurses made sure that patients had privacy when they needed it & 3,93 & 1,358 & 65,5 \\
\hline *22. Nurses had time to sit and talk to me & 2,92 & 1,574 & 48,7 \\
\hline 23. Doctors and nurses worked well together as a team & 4,76 & 1,016 & 79,3 \\
\hline *24. Nurses did not seem to know what each other was doing & 4,11 & 1,180 & 68,5 \\
\hline 25. Nurses knew what to do for the best results & 4,41 & 1,111 & 73,5 \\
\hline 26. There was a happy atmosphere in the ward, thanks to the nurses & 4,07 & 1,225 & 67,8 \\
\hline
\end{tabular}

* all negative questions were reversed during the data processing to be positive

On the questions "How do you evaluate the nursing care received in the ward”, using a 7-point Likert scale, where 1=awful, but 7=great, answers lower 
Beta et al., 2020. Patients'Satisfication as the Quality Indicator of Nursing

than 4 (average) were not obtained (see Figure 1). The average evaluation was 5.87 (see Table 3) which correspond to the evaluation 'good'.

Table 3 How do you evaluate the nursing care received in the ward

\begin{tabular}{|l|c|c|c|c|c|}
\hline & N & Min & Max & Mean & SD \\
\hline $\begin{array}{l}\text { How do you evaluate the nursing care } \\
\text { received in the ward? }\end{array}$ & 100 & 4 & 7 & 5,87 & 0,917 \\
\hline Total (N) & 100 & & & & \\
\hline
\end{tabular}

When comparing the satisfaction of patients with the length of stay (see Table 4), several patients were satisfied that the length of stay is 10 days or less $74.2 \%$, but this indicator is statistically insignificant $\chi 2=4,234, \mathrm{df}=2, \mathrm{p}=0,120$. When comparing the patients who stayed in the unit for 11-20 days, one half was satisfied, but the other half - unsatisfied.

Table 4 Cross-line tables of time spent in the unit and overall patients' satisfaction

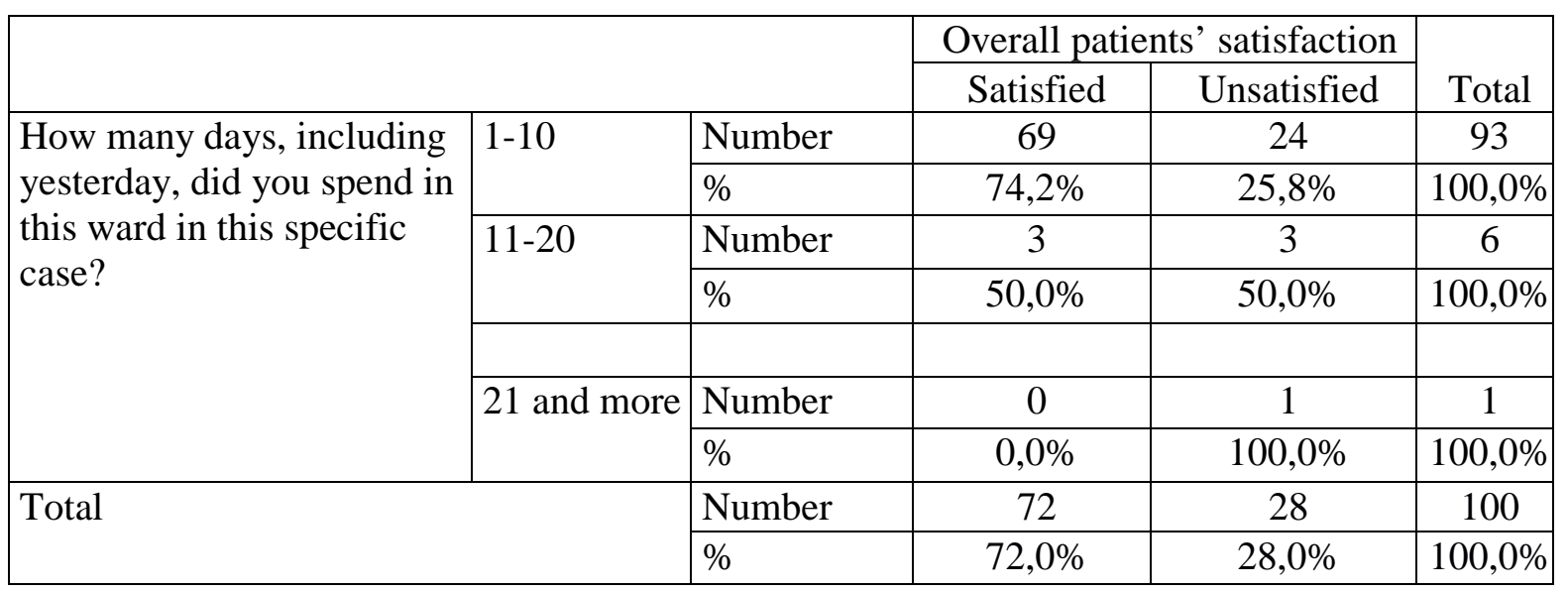

When analysing the sex of respondents and overall patients' satisfaction, it can be seen (see Table 5) that $77.4 \%$ of women and $66.7 \%$ of men are satisfied with nursing care. So, women are more satisfied than men - but this coherence is statistically insignificant $\chi^{2}=0,902, \mathrm{df}=1, \mathrm{p}=0,342$.

Table 5 Cross-line tables of sex and overall patients' satisfaction

\begin{tabular}{|c|c|c|c|c|c|}
\hline & \multicolumn{2}{|c|}{ Overall patients' satisfaction } & \multirow[b]{2}{*}{ Total } \\
\hline & & & $\overline{\text { Satisfied }}$ & Unsatisfied & \\
\hline \multirow[t]{4}{*}{ Sex } & \multirow[t]{2}{*}{ male } & Number & 26 & 13 & 39 \\
\hline & & \% & $66,7 \%$ & $33,3 \%$ & $100,0 \%$ \\
\hline & \multirow[t]{2}{*}{ female } & \begin{tabular}{|l} 
Number \\
\end{tabular} & 46 & 15 & 61 \\
\hline & & $\%$ & $75,4 \%$ & $24,6 \%$ & $100,0 \%$ \\
\hline & & Number & 72 & 28 & 100 \\
\hline & & $\%$ & $72,0 \%$ & $28,0 \%$ & $100,0 \%$ \\
\hline
\end{tabular}


When analysing the age of respondents and overall patients' satisfaction (see Table 7) coherence can be seen that the greatest patients' satisfaction (86.1\%) can be seen in the age group ' 65 and above', when compared with $50 \%$ in the age group ' $18-35$ ' and $69.6 \%$ in the age group ' $36-65$ ', however this indicator is statistically insignificant $\chi 2=8,012, \mathrm{df}=2, \mathrm{p}=0,18$.

Table 6 Cross-line tables of age and overall patients' satisfaction

\begin{tabular}{|c|c|c|c|c|c|}
\hline & \multicolumn{2}{|c|}{ Overall patients' satisfaction } & \multirow[b]{2}{*}{ Total } \\
\hline & & & Satisfied & Unsatisfied & \\
\hline \multirow[t]{6}{*}{ Age } & \multirow[t]{2}{*}{$18-35$} & Number & 9 & 9 & 18 \\
\hline & & $\%$ & $50,0 \%$ & $50,0 \%$ & $100,0 \%$ \\
\hline & \multirow[t]{2}{*}{$36-64$} & Number & 32 & 14 & 46 \\
\hline & & $\%$ & $69,6 \%$ & $30,4 \%$ & $100,0 \%$ \\
\hline & \multirow[t]{2}{*}{65 and above } & Number & 31 & 5 & 36 \\
\hline & & $\%$ & $86,1 \%$ & $13,9 \%$ & $100,0 \%$ \\
\hline \multirow[t]{2}{*}{ Total } & & Number & 72 & 28 & 100 \\
\hline & & $\%$ & $72,0 \%$ & $28,0 \%$ & $100,0 \%$ \\
\hline
\end{tabular}

The common connection of level of patient care between sex, age, length of stay and satisfaction didn't show any statistically important results.

\section{Conclusions and discussion}

The obtained results show that the overall satisfaction of patients with the care provided by nurses is at comparatively high level $(73.0 \%$ and $75.1 \%)$. Similar results were obtained in the research carried out in Turkey (Akin \& Erdogan, 2007) where $70 \%$ of patients were satisfied, and in the research carried out in Italy (Palese et al., 2017), where satisfaction was detected in $77.6 \%$ of patients. In the research carried out in Poland (Ozga et al., 2014), 78\% of patients were satisfied which is only a bit better indicator. A larger number of respondents is needed to obtain convincing results on the connection of satisfaction with demographical data.

Total impressions about patient-care are lower (67\% and 67.7\%). These results are almost identical with the results obtained by the group of researchers Ozga et al (Ozga et al., 2014) where patient's impressions reach 68.05\%, but the results obtained in the research performed by the group of researchers GutuszWojnicka etc. (Gutysz-Wojnicka et al., 2013) are a bit higher - 73.22\%.

The question "Nurses explained me my health condition" that got the worst results, in a patient's opinion, is not a duty of nurse at all, and a negative evaluation means not that nurses didn't fulfil their duties, but that such task doesn't correspond to their profession. 
The research results show a very significant lack in the performance of nursing care, which is the field of provision of information, education. So, the statements "Nurses explained me my health condition" and "Nurses did not tell me enough about my treatment" got very low results. This field requires improvements, thus potentially improving also patients' satisfaction.

Almost only half of respondents recognized that nurses knew themselves what to do without relying on doctors. In the society, also among the patients, there is a stereotype that a nurse only implements doctor's ordinations and is not able to educate patients about their health conditions or with treatment-related issues.

Similarly like in the research carried out by Akin et al (Akin et al., 2007), the statement "Doctors and nurses worked well together as a team" and "How capable nurses were at their job" got good results. However, unlike the research of the group of researchers Alasad et al., (Alasad, Abu Tabar, \& AbuRuz, 2015) where the question "How quickly nurses came when you called for them" got the lowest result, in this research this question got the best results. Also other questions related with technical skills, hot high results ("How quickly nurses came when you called for them", "Availability of nurses in cases of need", "How capable nurses were at their job"), which correlates with the research carried out by the group of researchers Maqsood et al., (Maqsood et al., 2012) where it was concluded that the technical abilities of nurses got the highest evaluation when compared with other dimensions, and it shows that nurses in Latvia are also technically well prepared, but the field of interpersonal skills needs improvements.

The results obtained in the cross-tables of the research are similar to the results of researches carried out by foreign authors (Ozga et al., 2014; Tang, Soong, \& Lim, 2013; Gutysz- Wojnicka et al., 2013) where no connection between individual demographical values (sex, age, education) and satisfactions is discovered. Here it is worth noting that connection with sex was detected in the researches of authors (Ozga et al., 2014; Akin et al., 2007; Oflaz et al., 2010; Liepaja Academy of Pedagogy, 2010; Alasad et al., 2015), drawing a conclusion that women are more satisfied with the nursing care, but in some researches, it was concluded (Palese et al., 2017; Milutinovic et al., 2012; Findik et al., 2010) that men are more satisfied with care.

When comparing the age of respondents with the total patients' satisfaction, results were obtained that the largest patients' satisfaction is in the age group "65 and above" which is similar to the conclusions drawn in the researches of foreign authors (Milutinovic et al., 2012; Akin et al., 2007; Gutysz- Wojnicka et al., 2013; Oflaz et al., 2010; Findik et al., 2010) that elderly patients are more satisfied with nursing care. 
It must be noted that NSNS questionnaire is developed in the United Kingdom, where, if compared with Latvia, nurses' duties are a bit different. There were some questions, which in the opinion of patients, were inappropriate to the nursing process in health-care institutions. For example, as to the question "Nurses had time to sit and talk to me" many respondents asserted that they understand that nurses have much to do and, although they would like to sit and talk to patients, they don't have time for this.

\section{Conclusions}

Determination of patients' satisfaction with nursing care experience in secondary health-care institutions is complicated and influenced by many factors. Important are also patients' relations with healthcare personnel, physical environment where nurses have crucial role when forming patients' experience about the stay in the hospital.

The obtained research results attest that nursing care must be efficiently improved to increase patients' satisfaction with it. It's necessary to improve the entrustable professional skills in communication and interpersonal relations. Each patient must be perceived as a person with his/her wishes and expectations about ideal nurses' communication, education and professional field where the best possible nursing must be ensured. The opinion that nurses need cooperate more actively with patients in their education is topical to change the stereotype that a nurse only implements doctor's ordinations and is not a health-care professional.

\section{References}

Ahmed, T., Assefa, N., Demisie, A., \& Kenay, A. (2014). Levels of Adult Patients' Satisfaction with Nursing Care in Selected Public Hospitals in Ethiopia. International Journal of Health Sciences, 8(4), 371-379. Retrieved from http:// www.ncbi.nlm.nih.gov/ pmc/articles/PMC4350891/

Akin, S., \& Erdogan, S. (2007). The Turkish version of the Newcastle Satisfaction with Nursing Care Scale used on medical and surgical patients. Journal of Clinical Nursing, 16, 646653. DOI:10.1111/j.1365-2702200601583.x

Alasad, J., Abu Tabar, N., A., \& AbuRuz, M.E. (2015). Patient satisfaction with nursing care: measuring outcomes in an international setting. JONA: The Journal of Nursing Administration, 45(11), 563-568. DOI: 10.1097/NNA.0000000000000264.

Findik, U.Y., Unsar, S., \& Sut, N. (2010). Patient satisfaction with nursing care and its relationship with patient characteristics. Nursing \& health sciences, 12(2) 162-169. DOI:10.1111/j.1442-2018.20090051x

Gustafson, C. (2015). Barbara Dossey, phd, rn: Developing a Healing Approach in Nursing. Integrative Medicine: A Clinician's Journal, 14(5), 72-77. Retrieved from http:// www.ncbi.nlm.nih.gov/pmc/articles/PMC4712872/ 
Gutysz-Wojnicka, A., Dyk, D., Cudak, E., \& Ozga, D. (2013). Measuring patient satisfaction with the Polish version of the Newcastle Satisfaction with Nursing Scale. Scandinavian Journal of Caring Sciences, 27, 311-318. DOI:10.1111/j.1471-6712201201034x

Kvist, T., Voutilainen, A., Mäntynen, R., \& Vehviläinen-Julkunen, K. (2014). The relationship between patients' perceptions of care quality and three factors: nursing staff job satisfaction, organizational characteristics and patient age. BMC Health Services Research, 14, 466. DOI:org/10.1186/1472-6963-14-466

Liepājas Pedagogiijas akadēmija Socioloǵisko pētījumu centrs. (2007). SIA „,Liepājas regiionālā slimnīca" pacientu viedoklı, kas raksturo vides, pacientu un personāla komunikācijas kultūru. Pieejams

http://liepajasslimnica.lv/files/pacvert/aptauja_kopejais_21.08.pdf

Maqsood, A.S., Oweis, A.I., \& Hasna, F.S. (2012). Differences between patients' expectations and satisfaction with nursing care in a private hospital in Jordan. International Journal of Nursing Practice, 18, 140-146. DOI:10.1111/j.1440-172X.201202008.x

Milutinović, D., Simin, D., Brkić, N., \& Brkić, S. (2012). The patient satisfaction with nursing care quality: the psychometric study of the Serbian version of PSNCQ questionnaire. Scandinavian Journal of Caring Sciences, 26, 598-606. DOI: 10.1111/j.14716712201200969.x

Negarandeh, R., Babahadi, A.H., \& Mamaghani, J.A. (2014). Impact of regular nursing rounds on patient satisfaction with nursing care. Asian Nursing Research, 8(4), 282-285. DOI:org/10.1016/janr.2014.10.005

Oflaz, F., \& Vural, H. (2010). The evaluation of nurses and nursing activities through the perceptions of inpatients. International Nursing Review, 57, 232-239. DOI:10.1111/ j.1466-7657200900772.x

Ozga, D., Gutysz-Wojnicka, A., Wojtaszek, M., \& Lewandowski, B. (2014). Assessment of satisfaction with nursing in a group of patients with disorders of the nervous system based on the Newcastle Satisfaction with Nursing Scale (NSNS). Medical Review, 3, 224-231. Retrieved from http://cejsh.icm.edu.pl/cejsh/element/bwmeta1.element.desklight73df1062-7909-414c-b701-4791d962336c

Palese, A., Gonella, S., Fontanive, A., Guarnier, A., Barelli, P., Zambiasi, P., Allegrini, E., Bazoli, L., Casson, P., Marin, M., \& Padovan, M. (2017). The degree of satisfaction of in-hospital medical patients with nursing care and predictors of dissatisfaction: findings from a secondary analysis. Scandinavian Journal of Caring Sciences, 31(4), 768-778. DOI: $10.1111 /$ scs.12396.

Slimību profilakses un kontroles centrs. (2017). Statistikas dati par ārstniecības personu skaitu. Pieejams https://spkc.gov.lv/lv/statistika-un-petijumi/statistika/veselibas-aprupes-statisti ka1/get/nid/14

Tang, W.M., Soong, C.Y., \& Lim, W.C. (2013). Patient satisfaction with nursing care: a descriptive study using interaction model of client health behavior. International Journal of Nursing Science, 3(2), 51-56. DOI: 10.5923/j.nursing.20130302.04.

Ten Cate, O., Chen, H.C., Hoff, R.G., Peters, H., Bok, H., \& van der Schaaf, M. (2015). Curriculum development for the workplace using entrustable professional activities (EPAs): AMEE guide no. 99. Medical teacher, 37(11), 983-1002. 